Religious Studies (2022) 58, 79-95 두 The Author(s), 2020. Published by Cambridge University Press doi:10.1017/S0034412520000177

\title{
Can a worship-worthy agent command others to worship it?
}

\author{
FREDERICK CHOO \\ Department of Philosophy, Nanyang Technological University, 48 Nanyang Avenue, \\ Singapore 639818, Singapore \\ e-mail:fcwy1@hotmail.com
}

\begin{abstract}
This article examines two arguments that a worship-worthy agent cannot command worship. The first argument is based on the idea that any agent who commands worship is egotistical, and hence not worship-worthy. The second argument is based on Campbell Brown and Yujin Nagasawa's (2005) idea that people cannot comply with the command to worship because if people are offering genuine worship, they cannot be motivated by a command to do so. One might then argue that a worship-worthy agent would have no reason to issue a command to worship. I argue that both these arguments fail.
\end{abstract}

I cannot conceive otherwise than that He, the Infinite Father, expects or requires no worship or praise from us, but that He is even infinitely above it.

Benjamin Franklin (1728)

\section{Introduction}

Suppose you meet Mother Teresa, who does many great moral acts and seems to have a good moral character. You believe she is very praiseworthy. Then you discover that she has been commanding people to praise her. This seems to create some doubt about her praiseworthiness. Perhaps you were wrong. An agent who commands others to praise them does not seem to be truly praiseworthy. Intuitively, Mother Teresa is not what you originally thought. Theists who belong to Abrahamic religions face a similar worry. Most theists believe that God is a worship-worthy agent and also believe that God has commanded us to worship him. ${ }^{1}$ However, as in Mother Teresa's case, one might think that any agent who commands others to worship him cannot be truly 
worship-worthy. If this is right, then theists cannot believe that God is a worshipworthy agent and also believe that God has commanded us to worship him.

This article examines two arguments to think that a worship-worthy agent cannot command worship. The first argument is based on the idea that any agent who commands worship is egotistical. This seems to explain why we think Mother Teresa would not be truly praiseworthy if she went around commanding others to praise her. Mother Teresa's act of commanding praise reveals her egotistical nature. The second argument is more complicated and draws from a recent article from Campbell Brown and Yujin Nagasawa (2005). Brown and Nagasawa argue that it is impossible for people to comply with the command to worship because if people are offering genuine worship, they cannot be motivated by a command to do so. One might then argue that if an agent commands worship, it must be the case that either (a) the agent fails to recognize that people cannot comply with such a command or (b) the agent recognizes people cannot comply with such a command but commands worship anyway. If (a) is true, the agent does not seem so wise, and hence seems unworthy of worship. If (b) is true, the agent seems to issue commands without reason, and hence seems unworthy of worship. My goal in this article is to argue that both of these arguments fail.

\section{The concept of worship}

Before moving further, we need to have a rough concept of worship. Worshipping seems to consist of two components. The first component is some mental state towards the object of worship; and the second component is an act, such as a ritual, that expresses that very mental state. For example, believers often gather together to sing songs, prostrate and pray, and recite scriptures together. Without the appropriate mental state, the acts and rituals do not count as genuinely worshipping. Many thinkers have noted that the mental state involved in worship is a complex one. Perhaps it is even sui generis and not reducible to any other mental state(s). Still, it seems that we can offer some analysis of this mental state.

First, worship seems to involve gratitude and praise. In worship, theists often thank God for the goods he has given to them, and they praise God for his greatness. But worship involves more than this. I am not worshipping my parents when I express gratitude to them for taking care of me. I am not worshipping a fireman when I praise him for being heroic. Another aspect of worship is being in awe. Mark Wynn (1999, 151), for example, says that worship is not primarily about 'giving thanks to a benefactor, or praising the remarkable greatness of a particular individual'. Instead, Wynn (ibid., 150-151) takes worship to be primarily about wonder and awe. Often, the phenomenon of worship does seem to involve being in awe of the worshipped. Christians have worship songs such as 'I Stand in Awe', 'Amazing God', and 'God of Wonders'. 
Worship also seems to involve reverence (i.e. deep respect). As Richard Swinburne $(2016,285-289)$ notes, worship involves the greatest possible explicit respect. In worship, theists take God as morally superior, much more powerful, and vastly greater than oneself (Bayne \& Nagasawa (2006), 300-301). In fact, many theists hold that a worship-worthy agent is not just vastly greater in comparison to its worshipper. A person might be a fool in general, but when compared to Hitler, he is vastly morally better. Still, that person is not worthy of Hitler's worship. Similarly, an agent who is morally superior to me but is still not morally perfect does not seem worthy of worship. For such reasons, theists often hold that an agent who is worship-worthy must be maximally great, free from imperfections (see for example Crowe (2007), 473; Swinburne (2016), 289; Murphy (2017), 130-131). Finally, worship seems to involve love. In worship, theists often sing songs of love to God. To sum up our analysis, worship involves gratitude, praise, being in awe, reverence, taking the worshipped as maximally great, and love. All of these aspects of worship can be found in the analyses of many other thinkers (see for example Smuts (2012), 222; Bayne \& Nagasawa (2006), 300-301; Swinburne (2016), 285-289).

\section{The Egotistical Objection}

Now we can look at the first argument that a worship-worthy agent cannot command worship. The first argument is based on the idea that seeking to be worshipped shows something morally deficient in an agent (Aikin (2010), 108-109; Cahn (2017), 12, 16). Most commonly, I hear complains about God being an egomaniac or being prideful for commanding worship. ${ }^{2}$

Call this following argument the Egotistical Objection:

1. If an agent commands worship, then that agent is egotistical.

2. If an agent is egotistical, then that agent cannot be worship-worthy.

3. Therefore, if an agent commands worship, then it cannot be worshipworthy.

Now, one might distinguish between the vices of being egotistical, vain, prideful, narcissistic, attention-seeking, and excessively self-absorbed. The term 'egotistical' above is meant to be used broadly and capture all these vices. I'll henceforth use the term 'egotistical' or 'prideful' to represent this group of vices.

In support of (1), recall the example of Mother Teresa commanding others to praise her. It is intuitive to think that Mother Teresa is egotistical for commanding praise. After all, we usually judge a person as egotistical if the person craves praise and attention. Let's move to (2). We have said in the previous section that a worship-worthy agent is maximally great. However, an egotistical agent is not maximally great. Such an agent is not even morally superior to many people. An egotistical agent does not even seem praiseworthy, let alone worship-worthy. 


\section{The Piecemeal Reply}

To reply to the Egotistical Objection, one might object to (1) by examining what it means to be prideful and argue that an agent would not necessarily be prideful for commanding worship. Paul Copan (2006, 315), for example, takes pride to be present when an agent 'think[s] of himself more highly than he ought to think'. This concept of pride may be supported by accounts of humility that say that a person is humble as long as the person does not overestimate himself (Ben-Ze'ev (1993), 237; Flanagan (1990), 176). A prideful person might then be thought to be one who has an inflated view of himself. In addressing the Egotistical Objection, Copan (2006, 318) says: 'God's call for our worship is not because he thinks more highly of himself than he ought or because he has false beliefs about himself.' We can reframe Copan's idea like this: a worshipworthy agent can have an accurate view of itself, namely, believing that it is worship-worthy; and command worship based on that true belief. So, in order to command worship, a worship-worthy agent does not have to think that it is greater than it actually is. In fact, if a worship-worthy agent is maximally great, then it is unclear how it could even have an inflated view of itself since it already is maximally great. Therefore, if an agent is worship-worthy, it can command worship without an inflated view of itself. Hence, (1) is false. If a being commands worship, that agent is not necessarily egotistical.

Now of course the reply above depends on a certain concept of pride. However, there are competing accounts of pride, and as mentioned earlier, my usage of 'pride' is meant to refer to a group of vices such as being narcissistic and attention-seeking, and these vices may have different concepts. To reply to the Egotistical Objection, one might visit each account of pride (and the similar vices) and then argue that an agent would not necessarily be prideful for commanding worship on that account.

Here are two quick examples. One account of humility comes from Nancy Snow. ${ }^{3}$ Snow $(1995,210)$ argues that:

\footnotetext{
To be humble is to recognize your limitations, to take them seriously, and thereby to foster a realism in attitudes and behavior regarding self and others. Humility can be defined as the disposition to allow the awareness of and concern about your limitations to have realistic influence on your attitudes and behaviour.
}

In turn, we may think pride is about not recognizing our limitations or taking our limitations seriously. On this account, it is unclear how commanding worship would be prideful, so long as the agent is worship-worthy. A worship-worthy agent can command worship while acknowledging any limitations it has (if it even has any). Another account of humility has to do with acknowledging 'the role that other people and favourable circumstances play' (Nuyen (1998), 107). In turn, we may think pride is not acknowledging the role that other people and circumstances had to play. Pride has to do with an agent taking all the credit when the credit is not actually due to that agent alone. On this account, it is 
again unclear how commanding worship would be prideful so long as the agent is worship-worthy. A worship-worthy agent has its status independent of other people and circumstances. So, there is no need for acknowledgement of the role that other people and circumstances have to play. Perhaps one might modify this account to say that pride is not acknowledging the good qualities and achievements of others. Still, it is unclear how commanding worship entails that the agent does not acknowledge the good qualities and achievements of others. A worshipworthy agent may command worship and also give credit whenever credit is due. In fact, Copan $(2006,315,321)$ points out that the Christian God does not take credit for the free choices which humans make and even praises humans in many scenarios. Hence, on all these accounts, (1) is false. If a being commands worship, that agent is not necessarily egotistical.

Call the above approach of looking into the different concepts of pride and arguing that (1) fails on each plausible concept of pride the Piecemeal Reply. What about the intuition that someone who commands worship seems egotistical? Proponents of the Piecemeal Reply can try to account for this intuition. When we think of someone commanding worship, we often think of human persons commanding worship. These human persons are not worship-worthy in the first place. For such human persons to command worship, it must be the case that they have an inflated view of themselves, they do not take their limitations seriously, and so forth. Hence, on many accounts of pride, they are indeed prideful. We are right in judging them as egotistical for commanding worship. Our intuitions are really tracking whether the agent has an inflated view of itself, whether the agent recognizes their limitations, and so forth. This intuition, however, cannot be applied to a worship-worthy agent like God. When a worship-worthy agent commands worship, it does not have an inflated view of itself, it does not have limitations to recognize, and so forth. So the intuition in Mother Teresa's case cannot be applied to a worship-worthy agent.

Despite the merits of the Piecemeal Reply, it faces difficulties with several accounts of pride. Here are just two examples. One account says that humility has to do with being unconcerned about the social status others attribute to us (Roberts \& Wood (2003); Peterson (2017)), or de-emphasizing one's good qualities in front of others (Ridge (2000)). In turn, pride would be an excessive concern for positive social recognition or be about flaunting one's good qualities to others. A second account of humility has to do with having motivated inattention to one's own good qualities (Bommarito (2013); see Garcia (2006) for a similar account). Pride would be an excessive concern over one's good qualities. On both these accounts, any agent who commands worship might be thought of as prideful. If an agent commanded worship, it is plausible that the agent does so because it is excessively concerned about getting social recognition. It is also highly plausible that an agent commands worship because it is excessively concerned about its good qualities and wants to call attention to them. Also, such an agent is easily 
seen as someone who is excessively trying to flaunt its good qualities to others. Hence, on these plausible accounts of pride, (1) seems true.

\section{The Non-Egotistical-Reasons reply}

I want to suggest a better reply to the Egotistical Objection. What seems to drive the intuition for (1) is that we think the reasons for commanding worship are egotistical reasons. For example, we might think that when agents command worship, they do so to gain social recognition, or because they are excessively concerned over their own good qualities. I want to suggest that there are some nonegotistical reasons for a worship-worthy agent like God to command worship. The first reason for commanding worship is that worship is good for the worshippers in terms of well-being and their moral characters. The second reason is that worship allows worshippers to have a better relationship with the worship-worthy agent. Commanding worship for both these reasons does not seem egotistical. If a worship-worthy agent's reasons to command worship are such non-egotistical reasons, then it can command worship.

\section{Worship is good for worshippers}

Let us look into the first reason I suggested, that worship is good for the worshippers. In the earlier section, I noted that awe is a key aspect of worship. Empirical studies show that the experience of awe has many positive effects. One positive effect is that it promotes humility. In a recent series of studies, Jennifer Stellar et al. (2018), show that experiences of awe result in a diminished sense of self that promotes humility. Through the experience of awe, participants held a more realistic view of themselves and presented a more balanced view of their strengths and weaknesses to others. Awe not only affected how the participants viewed and presented themselves, but it also affected how they viewed others. The study showed that participants were also more willing to acknowledge the role of outside forces in their own personal accomplishments. Katie McShane (2018) reports other positive effects of awe from various studies. Awe benefits a person by making the person happier and results in producing prosocial behaviour (McShane (2018), 475-475). McShane (ibid., 474) notes that some of these effects persist even after the experience of awe is over. So, experiencing awe is good for the person who experiences awe in many different ways. It gives them positive emotions, keeps them humble, and helps them to become better a moral agent by making them more inclined to prosocial behaviours. We can note here that this is not only good for the person who experiences awe, but an increase in prosocial behaviour will result in goods for those around the person who experiences awe.

It is plausible that the same might be said about other aspects of worship as well. Take, for example, gratitude. We can similarly say that being grateful and thankful 
keeps us happy and satisfied in life. Studies also show that being thankful increases prosocial behaviour in a person, even towards strangers (see for example Bartlett \& DeSteno (2006)). So the aspect of thanksgiving in worship can be emotionally beneficial for the worshipper and help the worshipper to be a better moral agent. Here, I do not mean to suggest that all aspects of worship will have all these benefits. For example, when we look at respect as an aspect of worship, it is unclear how learning to respect a worship-worthy agent keeps the worshipper happy. It is also unclear how that would improve the worshipper's moral character (though perhaps one might think that learning to respect a worship-worthy agent will lead a worshipper to respect others as well). But even if some aspects of worship have no positive effect on the worshipper, all that is needed here is the claim that worship as a whole has a positive effect on the worshipper. Given the different aspects of worship, it is highly plausible that worship helps people to experience positive emotions in their lives, such as amazement, thankfulness, fulfilment, and happiness. Worship also plausibly helps people become morally better agents by keeping them humble and increasing prosocial tendencies. One might of course add more positive effects to worship. Aaron Smuts $(2012,231)$, for example, suggests that the worshipper might be 'less troubled by existential concerns, and have a greater sense of purpose'. If worship benefits worshippers and makes them better moral agents, then a worship-worthy agent has good non-egotistical reasons to command worship.

This point fits nicely with how some theists read their scriptures. For example, a Muslim might say that God cannot be harmed or benefited. As God says in Sahih Muslim 2577a, 'O My servants, you can neither do Me any harm nor can you do Me any good.' Since God cannot be harmed or benefited by human persons, God plausibly does not command worship for egotistical reasons. If worship is not for God's benefit, it is highly plausible that worship is commanded for the good of the worshippers instead. For example, Quran 16:49 seems to suggest that God commands worship in order to help keep people humble. Similarly, Quran 2:21 asks humans to worship God so that they may become righteous. Therefore, God plausibly commands worship for the good of the worshippers.

\section{Worship improves the worshipped-worshipper relationship}

Let us turn to the second reason I suggested, that worship allows worshippers to have a better relationship with a worship-worthy agent. First, worship improves the relationship by helping a person to focus on the worship-worthy agent and its good qualities. In worship, the worshipper has to focus on the great properties that the worship-worthy agent has, and the good things which the agent has done for them. For example, in worship, theists often reflect upon the good things that they believe God has done for them. This helps theists to feel closer to God and thereby foster a better relationship with him. We see examples in real life as well. When we do not take time out to reflect upon the good 
qualities of our loved ones and the good things they have done for us, we often take them for granted. By focusing on these goods, we better appreciate our loved ones, feel closer to them, and thereby have a better relationship with them. For this reason, many people set aside special times to appreciate others, such as birthdays, Mother's Day, and so forth.

Second, worship plausibly helps a worshipper to know a worship-worthy agent more. Joshua Cockayne and David Efird (2018) argue that worshipping God helps theists to experience and know God. Cockayne and Efird appeal to Eleonore Stump's example of personal knowledge via second-personal experience. Suppose 'Mary is brought up in a room in which she has access to only third-personal propositional information about the world. What would Mary learn, Stump asks, when she encounters her mother for the first time, for example?' (Cockayne \& Efird (2018), 302; see also Stump (2010), 52-53). It seems that Mary would gain some personal knowledge of her mother. For example, she will no longer just have propositional knowledge that her mother loves her, but she will know what it is like for her mother to love her. She gains personal knowledge through a second-personal experience with her mother. This knowledge is simply not reducible to third-personal propositional information. Cockayne and Efird then argue that different rituals, such as worship, can provide second-personal experiences of God. Therefore, worship would allow the believer to gain personal knowledge of God (Cockayne \& Efird (2018), 308-311). Cockayne and Efird (ibid., 311-322) further argue that corporate worship (i.e. believers worshipping together) helps a believer to know God even more than in individual worship. This is based on the idea that when we meet a person with their other friends, we get to know them better than if we just met them alone. When we meet a person with their other friends, we often get to see different sides of the person, and it also helps to remove biases and impairments that alter our judgements and perception of the person. Cockayne and Efird conclude that worship, both individual and corporate, provides personal knowledge of God. It is plausible then that worship helps the worshipper to know a worship-worthy agent more.

Third, worship plausibly helps worshippers to enjoy a worship-worthy agent and feel a greater connection to it. C. S. Lewis says:

\footnotetext{
I think we delight to praise what we enjoy because the praise not merely expresses but completes the enjoyment; it is its appointed consummation. It is not out of compliment that lovers keep on telling one another how beautiful they are; the delight is incomplete till it is expressed. It is frustrating to have discovered a new author and not to be able to tell anyone how good he is; to come suddenly, at the turn of the road, upon some mountain valley of unexpected grandeur and then to have to keep silent because the people with you care for it no more than for a tin can in the ditch; to hear a good joke and find no one to share it with (the perfect hearer died a year ago). (Lewis (1986), 95)
}

For this reason, Lewis (ibid., 97) says that when God commands us to worship him, God is actually inviting us to enjoy him. Lewis here is not alone. I often hear theists link worship to enjoyment of God. Andrew Loke, a Christian philosopher, once 
commented to me that worshipping God is like getting to express oneself when watching a soccer match. ${ }^{4}$ Imagine you are watching your favourite team score a goal, but you are forbidden from reacting in any way. While you are happy that the goal is scored, something is missing. You only get to fully enjoy the soccer team scoring when you get to express yourself, such as leaping from the couch and shouting 'Goal!' By doing so, you also feel connected to the team. Therefore, it is highly plausible that worship helps people to enjoy God. Indeed, Bayne and Nagasawa $(2006,309)$ note that '[a]ccording to most theists, we are designed to worship God, and our true fulfillment and happiness is found only in such an activity'. We can take the soccer analogy further. Many people feel even more connected to the team and a greater sense of enjoyment when they are cheering alongside a group of fans for the same football team. Similarly, having religious believers gather together to worship God plausibly helps them to feel even more connected to God and helps them to have a greater sense of enjoyment. Just as we feel more connected to people when we enjoy them, theists often report that enjoyment of God helps them feel a greater connection to God. Hence, through enjoying worship, a worshipper can have a better relationship with a worship-worthy agent.

The above considerations suggest that there are plausible non-egotistical reasons for a worship-worthy agent to command worship. Through worship, worshippers can lead happier lives, become better moral agents, and can have a better relationship with a worship-worthy agent. If a worship-worthy agent's reasons to command worship are such non-egotistical reasons, then it can command worship.

\section{Objection: worship undermines autonomy}

One might object that despite these goods, worship is bad for worshippers because it undermines their moral autonomy. Indeed, James Rachels (1997, 109-123) and Scott Aikin (2010) have both argued that worship would undermine the worshipper's moral autonomy because worship requires unconditional obedience.

In reply, a worship-worthy agent could (and would) issue commands in a way that avoids undermining our autonomy. C. Stephen Evans $(2013,97)$ says that if God gave detailed instructions on a minute by minute basis for every detail of their lives then ... human persons would not need to use their rational faculties or develop them in order to know how to live'. However, God can give general and highly abstract commands which would require that 'humans fully engage their rational faculties to understand its implications and apply it' (ibid., 97-98). We can divide Evans' point into two parts. One issue is the frequency of the commands. If an agent issues commands to us too frequently, then there would be no room for us to make decisions. If an agent always told us what to do in every moral scenario, then it seems right that worship would undermine our moral autonomy. 
To avoid undermining our autonomy, a worship-worthy agent would not issue commands too frequently, leaving us space to exercise our autonomy. The second issue is the specificity of the commands. If an agent commands us to do specific acts, then this might undermine our autonomy. For example, in a story found in both the Quran and the Bible (Quran 2:35; Genesis 2:16-17), God forbids Adam and Eve to eat from one tree, but allows them to eat from any other tree which they choose. If God had instead commanded them to eat from a certain tree on one day, another tree on another day, and so forth, then this might leave no room for decision-making. But a worship-worthy agent can issue commands in ways which still leave sufficient room for human autonomy. For example, if a worship-worthy agent commands us to help the poor in general, we will have the space to decide when and how to fulfil such a command. Therefore, a worship-worthy agent can leave room for people to exercise their autonomy by ensuring that the commands are not too frequent and not too specific. Hence, unconditional obedience to another agent does not undermine a person's autonomy, given that the obedience is directed to a worship-worthy agent who would leave room for people to exercise their autonomy.

This reply might not satisfy Rachels and Aikin. Rachels (1997, 118-119) takes moral autonomy to be doing what one believes is right. Aikin $(2010,104)$ similarly says: 'Rational moral agency simply means that you think things through, you do what's right by your best lights, and that your actions are ones that come from you in the sense that you can be responsible for them.' Both of them might object that even if the commands are not too frequent and too specific, there might still be cases where the command might clash with what one believes is right. Unconditional obedience requires a person to act contrary to their moral belief in such cases. This violates their moral autonomy. Hence, unconditional submission requires a person to give up her moral autonomy (Rachels (1997), 118; Aikin (2010), 105).

In reply, religious believers often view God as a moral authority, in the sense that God can create legitimate moral obligations for us. If the worshipper believes that a worship-worthy agent can create legitimate moral obligations, then the worshipper would believe that he is morally required to do what the agent obligates him to do. Therefore, there would be no clash between the worshipper's moral belief and the command. The worshipper would just revise his or her moral beliefs upon hearing the command and act accordingly. Hence, their moral autonomy is not undermined.

Not everyone would take a worship-worthy agent as a moral authority. At minimum, however, we should think that a worship-worthy agent is an epistemic authority on moral matters, and would only issue commands in line with morality. If worshippers believe a worship-worthy agent exists, then they would believe that what the agent commands would be in line with morality. Therefore, there would once again be no clash between one's moral belief and the command. The 
worshipper would just revise his or her moral beliefs upon hearing the command and act accordingly. Hence, their moral autonomy is not undermined. ${ }^{5}$

Indeed, both Aikin $(2010,105)$ and Rachels $(1997,119)$ admit that there are cases where we can defer to others or obey authorities. As Akin (2010, 105) notes, we can defer to a person when we believe that the person is in a better epistemic position than us; and we obey authorities 'on the basis of the legitimacy of the institutions they represent'. However, Aikin (ibid., 105-106) says that such deference is conditional (and I suspect Rachels $(1997,120)$ would say something similar). A person's act of deference depends on the person believing that the agent in question is really an epistemic authority (or a moral authority). But certain commands may call this into doubt. Worship, however, seems to call for unconditional obedience (Aikin (2010), 104-105; Rachels (1997), 120).

In reply, the talk about 'conditional obedience' and 'unconditional obedience' here seems to confuse matters. It may be true that the concept of worship requires unconditional obedience. But whether a person chooses to worship is conditional: it depends (at least in part) on whether the person believes that the agent in question is a worship-worthy agent. As long as the person believes that an agent is worship-worthy, and hence is an epistemic authority (and perhaps even a moral authority), then the agent has good reasons to obey that agent. In other words, the unconditional obedience is directed towards an agent which a person judges is worship-worthy. Saying that the concept of worship requires unconditional obedience does not mean that a person should obey an agent, even if the person comes to believe that that agent is not worship-worthy. Hence, when an agent issues a command to worship, people have to exercise their moral autonomy to decide if that agent is worship-worthy. If they choose to worship (which requires obeying the agent for as long as they believe that agent is worship-worthy), their autonomy is not undermined since they recognize that agent as an epistemic authority and would revise their moral beliefs accordingly.

\section{The Impossible-to-Comply Objection}

Now we can turn to the second argument that a worship-worthy agent cannot command worship. Call this the Impossible-to-Comply Objection. This objection draws from on Campbell Brown and Yujin Nagasawa's (2005) argument that people cannot comply with a command to worship. Brown and Nagasawa argue for the following principle.

Impossible-to-worship-by-complying: It is impossible for people to comply with a command to worship.

In Brown and Nagasawa's article, they argue that Divine Command Theory is inconsistent with the view that we have an obligation to worship God. Brown and Nagasawa $(2005,139)$ take Divine Command Theory to include a compliance 
principle, which says that if God commands us to do an act, then we have a moral obligation to comply with the command to do that act. What does it mean to comply with a command? To comply with God's command, a person has to act according to God's command, and their motivating reason for acting as such has to be based on the command (Brown \& Nagasawa (2005), 140; see also Goldschmidt (2014), 144 and Miller (2015), 1). If a person is not motivated because of the command, then they are not complying with God's command. For example, imagine my parents command me to wash the dishes, but I do not care about what they want as I am angry with them. However, I still wash the dishes because I cannot stand the uncleanliness of the kitchen. My motivation for washing the dishes is solely due to my own desire to keep the place clean. Here, I am not complying with their command since I am not washing the dishes based on their command to do so.

Brown and Nagasawa (2005, 142-143) then go on to argue that people cannot genuinely worship God if their motivation to do so is based on God's command to worship (see also Bayne \& Nagasawa (2007), 478). This is because genuine worship must be a response to God's character or God's acts, but it cannot be a response to a command. The attitudes and emotions involved in worship entail that a person's motivation for worship cannot be based on a command. For example, I cannot express genuine gratitude to a person solely because the person commanded so. I can only express genuine gratitude to the person because the person has done something nice for me. So, if a person performs acts of worship and their motivating reason for doing so was due to God issuing the command, then they are not genuinely worshipping. Therefore, Brown and Nagasawa conclude that it is impossible for people to comply with a command to worship God.

Brown and Nagasawa $(2005,141)$ then appeal to the widely accepted oughtimplies-can principle, to say that 'God cannot issue any command with which it would be impossible for us to comply'. Hence, ought-implies-can and Impossible-to-worship-by-complying entail that God cannot command worship. Since divine command theory holds that all moral obligations come from God's commands, and God cannot command worship, there would be no obligation to obey God. Hence, divine command theory is at odds with there being an obligation to worship God. For the purposes of this article, we can set aside the concern with divine command theory. ${ }^{6}$ All that I am concerned with here is with Impossible-to-worship-by-complying. Given Impossible-to-worship-bycomplying, we can form the following argument:

4. If an agent commands worship, then either (a) that agent fails to know Impossible-to-worship-by-complying, or (b) that agent knows Impossible-to-worship-by-complying but still commands worship anyway.

5. If an agent fails to know Impossible-to-worship-by-complying, then that agent cannot be worship-worthy. 
6. If an agent knows Impossible-to-worship-by-complying but still commands worship, then that agent cannot be worship-worthy.

7. Therefore, if an agent commands worship, then that agent cannot be worship-worthy.

Let's look at (5). If Impossible-to-worship-by-complying is indeed true for the reasons given above, and an agent cannot recognize it, then it seems that the agent is not very wise or great. The agent would not be maximally great if it cannot recognize Impossible to-worship-by-complying, and hence would not be worthy of worship. Next, consider (6). Tyron Goldschmidt (2014, 169) has argued that 'we cannot comply with a command to believe in God. So a command to believe in God serves no purpose . . . Put the points together - a command to believe in God could serve no purpose, and God cannot issue commands with no purpose - to reach the conclusion that God cannot command us to believe in God.' Goldschmidt thinks that if we cannot comply with a command, then the command would serve no purpose and there would be no reason to issue it. This seems rather intuitive. After all, if an agent thinks it is impossible for us to do an act and still asks us to do it, what possible reasons could the agent have? Given that an agent who issues commands to others without reason does not seem worship-worthy, we should accept (6).

\section{Commanding others to act for the right reasons}

To reply to the Impossible-to-Comply Objection, one may argue that Impossible-to-worship-by-complying is false. Martijn Blaauw, for example, raises the following scenario:

\footnotetext{
John is a deeply religious man who prays regularly. He has never thought of worshiping God. One day, he reads the Bible and discovers that one is obliged to worship God. He considers this obligation for a few days, prays, and comes to the conclusion that God is indeed worthy of being worshiped. Accordingly, John starts to worship God. (Blaauw (2007), 239)
}

It seems that John can choose to comply with the command and even do so voluntarily. Therefore, Impossible-to-worship-by-complying is false in the first place.

I want to offer, however, a different reply from the Impossible-to-Comply Objection by arguing that (6) is false. Recall that the support for (6) is based on the idea that if people cannot comply with a command, then there is no reason to issue such a command to them. This, however, assumes that the only reason why an agent would issue commands is to get others to comply with the command. However, we often issue commands without wanting others to comply with them. Parents often issue commands to their young children such as, 'Be respectful!', 'Treat your siblings properly!', and 'Don't lie!' When parents issue such commands, it is odd to think that the only reason why they issue 
such commands is to get their children to comply. Parents would not want their children to treat their siblings properly solely because they commanded so. Rather, they would want their children to treat their siblings properly through being motivated by love for one another. So, by issuing such commands, parents are often not trying to get children to comply with the command. Instead, they command their children because they believe that doing so would causally promote doing the commanded acts for the right reasons.

Similarly, if a worship-worthy agent commands worship, the agent may have reasons other than getting people to comply with the command. A worshipworthy agent can command worship in order to causally promote performing acts of worship for the right reasons (such as being motivated by recognition of the agent's worship-worthiness). So, even though a worship-worthy agent knows Impossible-to-worship-by-complying, the agent can still have good reasons to command worship. Therefore, (6) is false.

Theists should gladly accept this. They often think that God commands us to love one another, or to do good to one another. It seems that theists do not think that God wants us to perform acts of love with the sole motivating reason being because God said so. Rather, many theists I come across take it that God wants us to perform acts of love with our motivation being genuine care and love for one another (see for example Miller (2015)). So theists should hold that God's reasons for issuing certain commands is not to get people to comply, but is to causally promote performing certain acts accompanied with the right motivating reasons.

One worry comes from Bayne and Nagasawa $(2007,478)$, who point out that the attitudes and emotions involved in worship do not seem to be under people's direct volitional control. Therefore, it seems that people cannot just voluntarily choose to comply with the command at will. After the command to worship is issued, people cannot just start performing acts of worship for the right reasons. So, one might wonder how commanding worship could causally promote acts of worship for the right reasons.

Two things can be said to address this. First, the command to worship plausibly does not extend to everyone. Instead, the command only extends to those who can already be motivated by the right reasons. For example, it would make no sense for any agent to demand gratitude from a person if that person does not believe that he or she has benefited from the agent. Similarly, in the case of God, one might think that atheists cannot be commanded by God, since they do not even believe in God in the first place (see Morriston (2009); Wielenberg (2014), 72-80; Danaher (2019)). If a worship-worthy agent only commands a selected group of people to worship, then that particular group might very well be able to worship voluntarily. Suppose the selected group of people have received many goods from this agent, they owe their existence to this agent, they stand in a personal loving relationship to the agent, and they recognize the worshipworthy agent to be maximally great. It seems that the selected group can choose 
to perform acts of worship while being motivated by the right reasons. They can recall the goods that they receive from the worship-worthy agent and be thankful, they can reflect upon the greatness of the worship-worthy agent and be in awe, and so forth. So as long as a worship-worthy agent commands a selected group of people, it is possible that by commanding them, this group can voluntarily choose to genuinely worship for the right reasons.

Second, while people might not have direct control over the attitudes and emotions involved in worship, they might have some indirect control. Swinburne (2016, 289), for example, says that the feelings of awe and respect involved in worship can be cultivated to some extent, just like other feelings. Blaauw makes a similar point. Blaauw $(2007,240)$ raises a case where "Going through the motions" of worshiping God actually resulted in [a person's] genuinely worshiping God. What this example shows is that worship can grow.' His point here is that performing acts of worship can result in genuine acts of worship over time. While it seems right that performing acts of worship can result in genuine acts of worship over time, one might find it objectionable for people to go through the motions of worshipping God without it being genuine. ${ }^{7}$ In reply, first, it does not seem to me that it is objectionable for a person to go through the motions of worship if that person is trying to do so in order to end up in genuine worship. Second, there are other ways of indirectly controlling one's attitudes and emotions that do not involve going through the motions of worship. Suppose someone commands you to trip accidentally. Obviously, you cannot voluntarily choose to trip accidentally, since if you choose to trip, it would not be an accident. You can, however, try to trip accidentally by putting yourself in situations in which you would trip accidentally. For example, you could ask your friend to lay a lot of obstacles on the ground for you to try to cross without tripping. Notice here that one does not go through the motions of tripping in the hope of tripping accidentally. Similarly, in the case of worship, people might perform different acts (which do not involve going through the motions of worship) in order to genuinely worship. People can learn more about how great the worship-worthy agent is, they can develop a loving relationship with the worship-worthy agent, they can record the goods that they have received from the worship-worthy agent and spend time reflecting on them, and so forth. All of these acts can help a person have the attitudes and emotions needed to worship. In doing so, one is following the command to worship for the right reasons.

\section{Conclusion}

In summary, I have argued that the two arguments for thinking that a worship-worthy agent cannot command worship fail. The Egotistical Objection fails because a worship-worthy agent can have non-egotistical reasons for commanding worship. The two plausible reasons are: worship is good for the worshippers, and that worship improves the relationship between the worshipper and the 
worship-worthy agent. The Impossible-to-Comply Objection fails because a worship-worthy agent can command worship without the aim of having people comply with the command. Instead, I argued that a worship-worthy agent could command worship because it wants to get people to perform acts of worship for the right reasons. Therefore, these two arguments fail to show that theists cannot consistently believe that God is worship-worthy and that God has commanded worship. ${ }^{8}$

\section{References}

Aiкin, Sсотт F. (2010) 'The problem of worship', Think, 9, 101-113.

Bartlett, Monica Y., \& Desteno, David (2006) 'Gratitude and prosocial behavior: helping when it costs you', Psychological Science, 17, 319-325.

Bayne, Tim, \& NAgasawa, Yujin (2006) 'The grounds of worship', Religious Studies, 42, 299-313.

Bayne, Tim, \& Nagasawa, Yujin (2007) 'The grounds of worship again: a reply to Crowe', Religious Studies, 43, 475-480.

Ben-Ze'Ev, Aaron (1993) 'The virtue of modesty', American Philosophical Quarterly, 30, 235-246.

BlaAuw, Martijn (2007) 'Worship me! A reply to Brown and Nagasawa', Ratio, 20, 236-240.

Bommarito, Nicholas (2013) 'Modesty as a virtue of attention', Philosophical Review, 122, 93-117.

Brown, CAmpbell, \& Nagasawa, Yujin (2005) 'I can't make you worship me', Ratio, 18, 138-144.

Cahn, Steven M. (2017) 'Why worship God?', Think, 16, 9-17.

Cockayne, Joshua, \& EFird, David (2018) 'Common worship', Faith and Philosophy, 35, 299-325.

Copan, Paul (2006) 'Divine narcissism? A further defense of God's humility', Philosophia Christi, 8, 313-325.

Crowe, Benjamin D (2007) 'Reasons for worship: a response to Bayne and Nagasawa', Religious Studies, 43, 465-474.

DANAHER, John (2019) 'In defence of the epistemological objection to divine command theory', Sophia, 58, 381-400.

Evans, C. Stephen (2013) God and Moral Obligation (Oxford: Oxford University Press).

Flanagan, Owen (1990) 'Virtue and ignorance', The Journal of Philosophy, 87, 420-428.

Franklin, Benjamin (1728) 'Articles of Belief and Acts of Religion, 20 November 1728', Founders Online, National Archives and Records Administration, <https://founders.archives.gov/documents/Franklin/o032> [accessed 30 November 2019].

GaRCIA, J. L. A. (2006) 'Being unimpressed with ourselves: reconceiving humility', Philosophia, 34, 417-435.

Goldschmidt, Tyron (2014) 'Commanding belief', Ratio, 28, 163-174.

Howell, Robert J. (2014) 'Google morals, virtue, and the asymmetry of deference', Noûs, 48, 389-415.

LewIs, C. S. (1986) Reflections on the Psalms (New York: Harcourt Brace).

Lillehammer, Hallvard (2014) 'Moral testimony, moral virtue, and the value of autonomy', Aristotelian Society Supplementary Volume, 88, 111-127.

McShane, Katie (2018) 'The role of awe in environmental ethics', The Journal of Aesthetics and Art Criticism, 76, 473-484.

Miller, Christian B. (2015) 'Some brief thoughts on 'commanding belief', Manuscript, <http://www.theapj. com/wp-content/uploads/2015/o6/Miller-Comment-on-Goldschmidt.pdf> [accessed 30 November 2019].

Morriston, Wes (2009) 'The moral obligations of reasonable non-believers', International Journal for Philosophy of Religion, 65, 1-10.

Murphy, Mark C. (2017) Gods Own Ethics: Norms of Divine Agency and the Argument from Evil (Oxford: Oxford University Press).

Nuyen, A. T. (1998) 'Just modesty', American Philosophical Quarterly, 35, 101-109.

Peterson, Claire Brown (2017) 'Humility in the deficient', Faith and Philosophy, 34, 403-424.

RACHeLs, JAMES (1997) 'God and moral autonomy', in Can Ethics Provide Answers? (New York: Rowman \& Littlefield), 109-123.

Ridge, Michael (2000) 'Modesty as a virtue', American Philosophical Quarterly, 37, 269-283. 
Roberts, Robert, \& Wood, Jay (2003) 'Humility and epistemic goods', in Michael DePaul \& Linda Zagzebski (eds) Intellectual Virtue: Perspectives from Ethics and Epistemology (Oxford: Clarendon Press), 257-279.

SMUTS, AARON (2012) 'The power to make others worship', Religious Studies, 48, 221-237.

SNow, NANCY E. (1995) 'Humility', The Journal of Value Inquiry, 29, 203-216.

Stellar, Jennifer E., Gordon, Amie, Anderson, Craig L., Piff, Paul K., McNeil, Galen D., \& Keltner, Dacher (2018) 'Awe and humility', Journal of Personality and Social Psychology, 114, 258-269.

Stump, Eleonore (2010) Wandering in Darkness: Narrative and the Problem of Suffering (Oxford: Clarendon Press).

Swinburne, Richard (2016) The Coherence of Theism (Oxford: Oxford University Press).

Whitcomb, Dennis, Battaly, Heather, Baehr, Jason, \& Howard-Snyder, Daniel (2015) 'Intellectual humility: owning our limitations', Philosophy and Phenomenological Research, 94, 509-539.

Wielenberg, ERIK J. (2014) Robust Ethics: The Metaphysics and Epistemology of Godless Normative Realism (Oxford: Oxford University Press).

Wynn, MARK (1999) God and Goodness: A Natural Theological Perspective (London: Routledge).

\section{Notes}

1. Some theists may believe that God has not commanded worship. For example, Copan (2006, 320) holds that the Bible does not teach that the call to praise comes from God. Instead, the call to praise comes from other humans.

2. Aikin $(2010,108-109)$ identifies a different vice. He says that an agent who commands worship is petulant. However, it is unclear to me how commanding worship entails that the agent is unreasonably annoyed or impatient in a childish way.

3. See also Whitcomb et al. (2015).

4. Andrew Loke, personal communication, 2017.

5. One might worry that moral deference undermines moral autonomy. Owing to space constraints, I can only direct the reader to see Hallvard Lillehammer (2014) and Robert J. Howell (2014), who reply to such worries.

6. For a response to Brown and Nagasawa, see Christian Miller (2015), who argues that Divine Command Theory does not need to include the compliance principle. Instead a Divine Command Theorist may hold that the motivating reason has to be "for the reasons for which the command was made" (ibid., 2).

7. I thank a reviewer for this point.

8. I like to thank Preston Greene, Esther Goh, and the reviewers at Religious Studies for helpful comments on this article. 